\title{
AKTUALISASI PEMBANGUNAN PARTISIPATIF DALAM FORUM KOMUNIKASI PEMBERDAYAAN PEREMPUAN DESA
}

\author{
Toto Sugito, Rili Windiasih, Adhi Iman Sulaiman \\ Universitas Jenderal Soedirman Purwokerto \\ totomyounsoed@gmail.com
}

\begin{abstract}
The research aims to cerat the model of communication forum for village women empowerment as the actualization of participative development (FPPD). The research used Participatory Rural Appration (PRA) research method that involves the role and potential of the community in a participatory to identify and find solutions to problems, and determine the needs that must be implemented by the community itself. Data were collected through Focus Group Discussion (FGD), interviews, observation, and documentation. Analysis of research used interactive analysis through reduction and presentation of data and conclusion. The research location in Sidaurip Village and Karangtawang Village, Cilacap Regency. The results showed that FPPD model have realization of participatory communication that important role in rural development to provide more opportunities for women in planning, implementation, and evaluation of empowerment programs and improving welfare.
\end{abstract}

Keywords: communication, empowerment, participatory, village, women

\section{PENDAHULUAN}

Perwujudan dari perjuangan reformasi, demokratisasi dan otonomi dalam proses perencanaan dan pelaksanaan pembangunan sampai ke tingkat paling dekat dengan rakyat pada level desa. Begitu penting dan strategisnya pembangunan di desa sebagai pondasi ekonomi bangsa dan negara, sehingga maju dan mundurnya ekonomi negara tergantung pada ekonomi desa. Pembahasan tentang pentingnya desa dalam pembangunan telah lama ditegaskan Chambers (1983) dengan konsep pembangunan desa mulai dari belakang yaitu desa. Kota merupakan etalase simbolik kemajuan pembangunan tetapi desa hakekatnya jantung perekonomian negara. Begitupun menurutAdi (2013) pembangunan menjadi kurang berarti, jika tidak memperhatikan pembangunan masyarakat lokal (desa) dan belum ada pengembangan secara keseluruhan di desa yang memiliki potensi dan sumber daya secara maksimal. Syahyuti (2006) menyatakan pembangunan partisipatif (participatory development) merupakan proses pelibatan secara aktif masyarakat dalam keputusan penting dalam kehidupan masyarakat. Rangkuti (2011) menjelaskan bahwa ada pergeseran paradigma pembangunan yaitu lebih menfokuskan pada pembangunan pemberdayaan (empowerment) untuk pembangunan manusia (people centered development), pembangunan berdasarkan potensi sumber daya lokal (resource based development) dan pengembangan kelembagaan (intitutional development). 
Berdasarkan semangat, dukungan dan keseriusan membangun desa tersebut, diharapkan desa bukan hanya kampung halaman yang dicintai dan dirindukan oleh salah satunya masyarakat desa yang menjadi Tenaga Kerja Wanita (TKW) khususnya kaum perempuan. Seharusnya desa bisa menjadi wilayah yang ramah, nyaman, menyenangkan dan menjamin kesejahteraan masyarakatnya, sehingga tidak ditinggalkan dan diabaikan pembangunanya. Pada saat ini muncul paradigma baru untuk kembali lagi dengan konsep membangun desa dan berubah menjadi konsep desa membangun, artinya pelaku pembangunan tidak lagi dominan dari orang di luar desa, tetapi masyarakat desa sendiri yang memiliki keinginan, inisiatif dan bekerja untuk desanya untuk memajukan serta mensejahterakan desanya. Semangat dan Konsep "Bali Deso, Bangun Deso" dan "Desa Membangun" merupakan aplikasi dari konsep pembangunan yang partisipatif, pembangunan yang berpusat pada rakyat dan pemberdayaan. Hal ini menjadi semangat dari peneliti untuk mewujudkan riset tentang pemberdayaan perempuan dalam pengembangan kewirausahaan desa khususnya bagi masyarakat desa yang menjadi pusat dan terbesar jumlah tenaga kerja di luar negeri yang berasal dari Jawa Tengah yaitu di Kabupaten Cilacap.

Artinya jika pengembangan pemberdayaan kewirausahaan di masyarakat dapat diwujudkan, maka masyarakat desa tidak lagi menjadi Tenaga Kerja Wanita (TKW)di desa yang masih menilai TKW menjadi orientasi utama dalam mencari kerja dan kesejahteraan. Masyarakat desa yang banyak calon, mantan dan menjadi TKW akan ada alternatif pekerjaan dan penghidupan sehingga bisa tinggal atau tidak meninggalkan desanya, karena ada pekerjaan dan sumber penghasilan di desanya.

Semangat dan konsep "Desa Membangun" akan tetap menjadi slogan dan motto kampanye politik dan pembangunan otonomi desa jika tidak ada suatu kajian dan pelaksanaan pengembangan kewirausahaan dalam program pemberdayaan desa yang membuat masyarakat desa khususnya perempuan mau tinggal untuk bekerja dan memiliki jaminan ekonomi di desanya, serta tidak lagi menjadi Tenaga Kerja Wanita (TKW) sebagai profesi yang paling utama dan menjanjikan kesejahteraan.

Slogan bagi TKW sebagai "pahlawan devisa" menjadi realitas yang masih terjadi, karena dapat mendatangkan pendapatan bagi negara dan seakan profesi yang selalu menjadi orientasi masyarakat desa dengan harapan besar dapat merubah nasib yang lebih baik dan lebih cepat mensejahterakan diri serta keluarganya. Namun pada realitas lainnya menunjukan tidak sedikit problematika yang muncul ke publik seperti proses pendaftaran, berangkat, bekerja dan pulang kembali bekerja ke daerah asalnya. Masalah TKW yang dimaksud seperti posisi dan katagori bekerja secara ilegal, kasus tuduhan kriminalitas seperti pembunuhan dan pencurian, kasus kekerasan psikologis, psikis, pelecehan seksual Tenaga Kerja Wanita (TKW). 
Pada tahun 2017 menurut Badan Nasional Penempatan dan Perlindungan Tenaga Kerja Indonesia (BNP2TKI) ada beberapa permasalahan tenaga kerja Indoensia, seperti pekerja menuntut pulang sebanyak 311, gaji tidak dibayar ada 271, TKI gagal berangkat 205, Overstay 193, kasus pemutusan hubungan kerja (PHK) sefihak 193, Sakit 186, putus hubungan komunikasi 129, pekerjaan tidak sesuai PK (Perjanjian Kerja) 110, perdagangan orang 68, TKI tidak berdokumen 65 , potongan gaji melebihi ketentuan 65 dan lain-lainnya sebanyak 695 pengaduan. Selain itu, BNP2TKI juga mencatat adanya pengaduan atas TKI meninggal, tidak punya ongkos pulang, mendapat tindakan kekerasan dari majikan dan sebagainya.

Lembaga Migrant CARE (2018) sebagai pehimpunan Indonesia untuk buruh migran berdaulat yang melansir data BNP2TKI, bahwa pada tahun 2017 perempuan masih dominan menjadi penempatan Pekerja Migran Indonesia (PMI) mencapai 70 persen dan kasus yang ditangani menunjukkan 84 persen korban adalah perempuan. Pekerja perempuan kondisinya terjebak kasus perdagangan manusia, pelanggaran kontrak kerja, gaji tidak layak, asuransi dan dokumen bermasalah. Berdasarkan hasil survey menunjukkan sebanyak 40 persen dari Tenaga Kerja Indonesia (TKI) memiliki jenjang pendidikan Sekolah Dasar (SD). Menjadi TKI karena tidak adanya pekerjaan, memiliki harapan mendapat upah yang lebih tinggi, supaya dapat menabung dan memiliki kehidupan lebih sejahtera, dan terjebak dalam ketidakmerataan atau ketimpangan yang membudaya .
Menurut Wulan (2010) bahwa TKW sering mengalami ketidakadilan yang dimulai dari sebelum pemberangkatan, ketika di tempat kerja sampai ketika kepulangan ke daerah asal. Padahal menjadi TKW bertujuan untuk memenuhi kebutuhan keluarga dan sebenarnya berkontribusi untuk devisa negara dan remiten untuk daerahnya.

Namun menjadi Tenaga Kerja Wanita (TKW) bagi masyarakat tertentu menjadi tawaran profesi yang menjanjikan kesejahteraan bagi dirinya dan keluarganya, sekalipun sudah banyak permasalahan. Kemudian tidak bisa dipungkiri TKW juga secara signifikan menghasilkan sumber pendapatan bagi devisa negara dan pendapatan asli daerah, sehingga membatu perkembangan pembangunan di daerah serta bagi keluarganya Berdasarkan data remitan di Kabupaten Cilacap sebagai daerah TKW terbanyak di Jawa Tengah yaitu jumlah remitansi atau uang yang ditranfer TKW dari Cilacap meningkat setiap tahunnya.

Hal ini bisa menjadi bukti bahwa warga Cilacap telah banyak yang menjadi TKW, menurut sumber media detik news (2017) bahwa BNP2TKI mengumumkan banyaknya jumlah TKI berdasarkan kabupaten dan kota, yang memiliki jumlah TKI tertinggi adalah Lombok Timur 10.621 orang, Indramayu 10.390 orang, Lombok Tengah 6.917 orang, Cirebon 6.408 orang, dan Cilacap 5.448 orang.

Dengan demikian sudah seharusnya Tenaga Kerja Wanita (TKW) menjadi perhatian serius dari stakeholder baik anggota dewan dan pemerintah (lokal dan nasional), dan aktivis penggiat pemberdayaan, serta akademisi atau perguruan tinggi mulai tingkat tingkat lokal di desa sampai pusat. 
Subianto (2006) menegaskan bahwa memerlukan political will pemerintah terutama dalam menumbuhkan kewirausahaan agar penghasilan TKW yang dikirimkan ke desa sebaiknya untuk kegiatan ekonomi yang lebih memiliki nilai atau manfaat yang berguna dan berhasil guna bukan untuk dipergunakan yang tidak produktif.

Adapun dukungan peraturan untuk mengadvokasi TKW, namun dalam realitasnya, belum mendapat dukungan oleh political will pemerintah lokal yang dapat dijadikan pondasi bagi perencanaan pembangunan di tingkat lokal. Dengan demikian harus ada keseriusan eksekutif merancang pembangunan dan pemberdayaan yang diarahkan untuk mencerdaskan masyarakat, terdapat pelayanan publik kepada tenaga kerja Indonesia dan keluarganya yang berada di daerah asal (Sutaat et al. 2011). Perhatian pemerintah terhadap TKW di Kabupaten Cilacap, menurut Libanun Muzayyin sebagai Ketua Badan Legislatif Daerah (Balegda) DPRD Cilacap, dalam kegiatan Workshop Jaringan Kepala Desa yang membahas komitmen pemerintah desa untuk lebih serius memperhatikan TKW dan keluarganya di daerah asal, sehingga Cilacap yang memiliki jumlah TKW terbanyak di Jawa Tengah dan termasuk yang terbesar di Indonesia, sebaiknya memiliki peraturan daerah yang khusus mengatur perlindungan, advokasi dan menejemen TKW secara komprehensif (sumber : http://polhukam.rmol.co/read). Berdasarkan hal tersebut, peneliti sangat peduli dan tertarik untuk ikut berperanserta memberikan solusi bagi permasalahan TKW dengan mengkaji dan melakukan penelitian.
Hasil penelitian dapat memberikan kontribusi positif untuk rekomendasi secara ilmiah yaitu membentuk Forum Komunikasi Pemberdayaan Perempuan Desa (FKPPD) dalam membuat, mengaspirasikan dan melaksanakan program pemberdayaan untuk menciptakan solidaritas, peningkatan kemampuan atau keterampilan usaha serta mensejahterakan perempuan khususnya bagi mantan dan calon TKW yang akan diperjuangkan salah satunya dalam Musyawarah Perencanaan Pembangunan (Musrenbang) desa dan kecamatan.

\section{METODE PENELITIAN}

Penelitin ini menggunakan Metode Participatory Rural Appraisal (PRA) yaitu mengkaji potensi masyarakat untuk saling memaknai dan melaksanakan unsur penting empowerment community (Syahyuti 2006). PRA merupakan metode penilain pedesaan yang partisipatoris dengan memberikan ruang bagi komunitas desa untuk menganalisis situasi secara maksimal, merancang dan mengimplementasikan program di lokasi masyarakat (Chambers dalam Mikkelsen, 2011).

Prosedur pengumpulan data kualitatif mempergunakan wawancara, observasi dan Focus Group Discussion (FGD) (Bungin, 2008). Tahapan pelaksanaannya yaitu wawancara dan observasi dilaksanakan dalam tahapan penelitian yaitu: (1) Pertama riset pendahuluan untuk observasi, menghimpun data untuk di analisis, pembukaan akses, kemudian merumuskan probematika yang 
ditemukan, sasaran penelitian dan metode penelitian. (2) Melakukan verifikasi data dan triangulasi hasil penelitian.

Pelaksanaan riset pada 2015-2017 di Desa Karangtawang Kecamatan Nusawungu dan Desa Sidaurip Kecamatan Binangun Kabupaten Cilacap Jawa Tengah sebagai desa yang mengirimkan TKW terbanyak di Jawa Tengah. Pemilihan informan melalui purposif sampling yang dipilih atas pertimbangan peneliti bahwa subjek penelitian dapat memenuhi kebutuhan dan tujuan penelitian. Setiap desa ditentukan sekitar 20 orang dari para calon dan mantan TKW, sehingga jumlah keseluruhan 40 informan dari dua desa, informan yang dipilih merupakan kelompok pekerja (community worker) yang akan merumuskan dan melaksanakan pembangunan serta agent of change untuk pembangunan desa.

Tahapan analisis penelitian yaitu (1) Mereduksi data, yaitu poses identifikasi, fokus kajian, dan katagorisasi data dari hasil pelaksanaan riset secara berkesinambungan selama kegiatan riset berlangsung. (2) Penyajian data dengan mengumpulkan, mengolah dan menganalisis data, kemudian penarikan simpulan dan implementasi. (3) Membuat simpulan atau dan memverifikasi yaitu tahapan terakhir dari tahapan pengumpulan data untuk dianalisis dengan cara memilih, mengkatagorikan, membuat model, dan mendeskripsikan (Miles \& Huberman 2007).

\section{PEMBAHASAN}

Masyarakat di desa khususnya kaum perempuan di Kabupaten Cilacap memiliki persepsi dan tradisi bahwa menjadi Tenaga Kerja Wanita (TKW) adalah profesi yang paling menjajikan dan mensejahterakan. Walaupun banyak sekali permasalahan menjadi TKW mulai proses keberangkatan, proses bekerja dan kepulangan, tetapi menjadi TKW masih dinilai paling menjanjikan, cepat mendapatkan banyak penghasilan. Namun dampak jangka panjangnya pembangunan di desa tidak dapat berkembang sesuai potensi sumber daya baik alam seperti pertanian dan peternakan serta sumber daya manusianya, sehingga desa hanya menjadi tempat mudik ketika musim libur panjang dan budaya mudik lebaran serta sebagai tempat kelahiran dan dibesarkan. Maka penting untuk melakukan kajian dan penelitian tentang komunikasi partisipatif dalam pemberdayaan perempuan khususnya di lokasi penelitian untuk meningkatkan kesejahteraan khususnya bagi mantan dan calon TKW. Penelitian dilakukan pada tahun 2015-2017, pada tahun 2015-2016 proses penelitian diawali dengan melakukan kajian pustaka dari berbagai hasil riset,jurnal dan realitas faktual di media massa, kemudian melakukan diskusi untuk hasil kajian pustaka untuk merancang rencana penelitian baik tujuan, sasaran, metode dan waktu pelaksanaan. Tahapan berikutnya melakukan pembukaan akses penelitian, mengajukan perijinan dan pendekatan kepada pemerintah desa, tokoh masyarakat, aktivis dan tokoh penggerak wanita. Pada awalnya peneliti mengalami 
kesulitan untuk mendapatkan ijin kepada pemerintah desa dengan sifat kehati-hatian, sensifitas dan ketertutupan pada pihak luar sangat tinggi. Hal tersebut dikarenakan (1) Sedang menghadapai masalah penambangan pasir dengan adanya konflik kebijakan, penggunaan dan alokasi anggaran. (2) Penyaluran tenaga kerja ke luar negeri melibatkan oknum lokal (calo) yang bermain dan menguasasi. (3) Kasus penipuan investasi saham yang dilakukan orang luar sehingga banyak masyarakat desa mengalami kerugian.

Tanggapan peneliti terhadap kasus tersebut dengan mengkomunikasikan kepada pemerintah desa, bahwa tujuannya bukan untuk meneliti atau mengungkap hal tersebut, tetapi berencana membuat dan melaksanakan proggram pemberdayaan. Hal tersebut dilakukan supaya tidak mendapat kecurigaan dan penolakan dari pemerintah desa dan informan. Dengan demikian target dan hasil penelitian tahun 2015-2016 yaitu identifikasi masalah, analisis potensi masyarakat desa dan tim peneliti dapat dijijinkan dan diterima untuk melakukan penelitian seperti proses wawancara, observasi langsung dan analisis dokumentasi.

Hal tersebut sebagai bentuk pelaksanaan komunikasi pembangunan atau pemberdayaan secara partisipatif, menurut Mefalopulos yang dikutip Dasgipta (2009) komunikasi berperan penting dalam pembangunan yang menghasilkan partisipasi, dialog, dan diseminasi pengetahuan penting (generating participation, dialogue, and dissemination of vital knowledge). Komunikasi dapat membantu, mendukung dan mengadopsi model pembangunan secara dialogis dan mengkolaboraiskan semua stakeholder dengan berbagi pengetahuan sebagai bentuk pendidikan masyarakat. Praktek komunikasi partisipatif dalam pembangunan, menurut Steeves (dalam Porras \& Steeves, 2009) diindikasikan dengan tatap muka dialogis secara egaliter, yang melibatkan refleksi, tindakan, dan tanpa perbedaan hirarki peserta dialog. Muchlis (2009) menyatakan pentingnya komunikasi partisipatif dalam program pemberdayaan masyarakat dapat mengakomidir keberagaman sumber daya ekonomi, sosial, agama dan budaya serta gender. Menurut Satriani (2011) komunikasi partisipatif memiliki dampak pada setiap kegiatan masyarakat yang bermanfaat untuk saling berbagi informasi, pengetahuan, dan menyelesaikan masalah secara bersama serta terjalinnya keakraban sesama.

Proses penelitian tersebut menggunakan komunikasi persuasif secara informal dengan menjaga etika komunikasi yang sopan, menjaga etika dan penekanan pada kebutuhan peneliti untuk banyak belajar banyak dari pengalaman para mantan dan calon TKW, bukan mau melakukan penelitian sehingga alasan permohonan ijin secara formal melalui surat resmi dibuat dengan keterangan pengabdian masyarakat. Respons informan akan cenderung tertutup dan menolak jika alasanya penelitian yang terkesan akan mengungkap kejelekan dan masalah, sehingga pengajuan pengabdian masyarakat lebih dapat diterima dan bersahabat. Peneliti mendapat ijin dan dukungan dari pihak 
pemerintah desa untuk melanjutkan penelitian, supaya bisa menghasilkan program kongkrit yang dibutuhkan masyarakat sebagai bentuk pemecahan masalah dan pengembangan potensi. Sebagaimana menurut Effendy (2005) komunikasi informal dalam proses interaksi sosial dapat mempunyai kekuatan dan pengaruh terhadap wewenang dan kebijaksanaan yang dikeluarkan secara formal. Hasil penelitain dari Sulaiman (2013) menjelaskan bahwa dalam proses pemberdayaan komunikasi yang bersifat informal tidak bisa dipisahkan dari komunikasi formal. Tahapanya komunikasi formal dilakukan setelah pembukaan akses dengan komunikasi informal terlebih dahulu melalui jalur pertemanan, kolega dan kekeluargaan dari informan kunci kepada informan kunci lainnya. Komunikasi formal melalui surat resmi akan lebih memperkuat pemberdayaan. Jika komunikasi informal gagal, maka terjadi penolakan dari subjek penelitian Dalam pemberdayaan khususnya pada proses pembukaan akses, selain komunikasi informal juga dengan komunikasi persuatif, sebagaimana DeVito (2011) menyatakan komunikasi persuasif dilakukan dengan memperkuat, memberikan gambaran atau contoh, dan informasi untuk mengubah dan menguatkan sikap serta perilaku dengan menggunakan fakta, opini, dan aspirasi yang memotivasi.

Tahap penelitian berikutnya tahun 20162017, setelah mendapatkan ijin dan dukungan pihak pemerintah desa untuk melanjutkan kegiatan, peneliti melakukan dialog dengan para mantan dan calon TKI di desa yang masih berada dalam kelembagaan pemberdayaan perempuan seperti lembaga Pembinaan Kesejahteraan Keluraga (PKK), artinya belum memiliki kelembagaan lainnya dibidang wirausaha ekonomi. Kemudian menyepakati dialog bersama di baledesa untuk kegiatan sarasehan atau sambung rasa sebagai pengganti kegiatan pengumpulan data yiatu Focus Froup Discussion (FGD). Mengkomunikasikan bentuk kegiatan berupa sarasehan sambung rasa lebih dapat diterima dengan baik, tidak terkesan formal dan lebih nyaman masyarakat untuk mengikutinya dalam hal ini informan perempuan. Mengkomunikasikan agenda kegiatan dialog sarasehan sambung rasa sebagai forum untuk mengeluarkan aspirasi, membuat solusi dan menyepakati program yang akan dilakukan bersama berdasarkan permasalahan yang dihadapi, kebutuhan dan potensi masyakarat. Kemudian menyepakati kegiatan baik dari segi waktu dan tempat ditentukan oleh para informan dengan difalitasi oleh peneliti, supaya tidak membebani para informan baik dari segi akomodasi, konsumsi dan perlengkapan media yang dibutuhkan dalam acara dialog. Kesepakatan melaksanakan kegiatan merupakan proses komunikasi interaksional, menurut Fisher et al. (1994) komunikasi interaksional terjadi antara pelaku komunikasi yang membangun potensi subjek berdasarkan hubungan sosial dengan roletaking with other atau memerankan orang lain. Kemudian proses komunikasi selanjutnya menuju pada komunikasi transaksional, West dan Turner (2008) menjelaskan bahwa 
komunikasi model transaksional prosesnya bersifat kooperatif diantara pelaku komunikasi memiliki konsekwensi terhadap komunikasi efektif serta aktif membangun kesamaan makna atau pemahaman secara terus menerus menerima dan mengirim pesan verbal dan nonverbal. Para pelaku komunikasi menegosiasikan makna, mengintegrasikan pengalaman dan membangun persamaan makna.

Berdasarkan temuan penelitian, maka dapat dirancang suatu model komunikasi pemberdayaan dalam proses dan hasil penelitian yang dapat disajikan pada Gambar 1.

Gambar 1 : Komunikasi dalam proses penelitian pemberdayaan

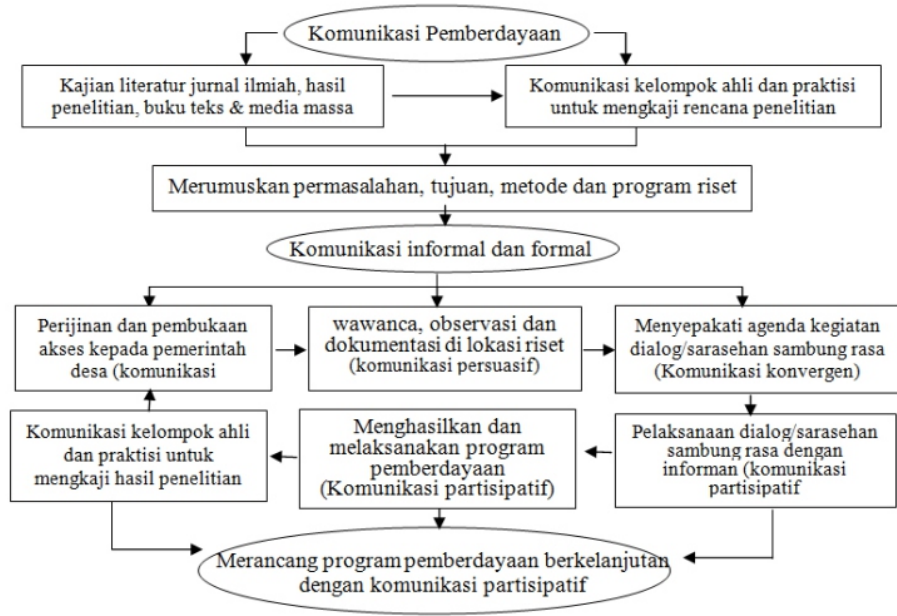

\section{Forum Komunikasi Pemberdayaan Perempuan Desa (FKPPD)}

Pemberdayaan dapat dilakukan oleh pihak luar (outsider) masyarakat untuk menjadi fasilitator, instuktur dan pendamping dengan melakukan intervensi positif tetapi secara partisipatif, hal ini dilakukan untuk menumbuhkan kesadaran dan motivasi masyarakat, membantu mengideintifkasi masalah dan potensi hingga membuat program kegiatan. Kemudian dapat juga dilakukan oleh masyarakat sendiri (insider) yang telah memiliki kesadaran dan motivasi untuk berubah, meningkatkan kemampuan dan kesejahteraan. Proses pemberdayaan tersebut tidak lepas dari peran penting komunikasi baik bentuk komunikasi maupun media komunikasi sebagaimana dalam Gambar 1. Pemberdayaan bukan saja memberikan atau membangun kemampuan dan kesejahteraan di bidang ekonomi seperti memberikan penyuluhan dan pelatihan usaha ekonomi masyarakat, membentuk kelembagaan usaha kecil dan menengah, pendampingan, perluasan akses pasar dan promosi serta kemitraan. Akan tetapi pemberdayaan secara politik yaitu adanya hak dan kesempatan berpartisipasi yang diberikan secara terbuka, lebih luas dan sejajar dalam proses perencanaan pembuatan program pembangunan sampai pemgambilan keputusan program pembangunan atau pemberdayaan. Pemberdayaan secara politik sangat penting dan strategis karena sebagai pijakan awal untuk menentukan program, anggaran dan pelaksanaannya khususnya bagi mantan dan calon TKW yang notabene masih terdiskriminasi untuk berpartisipasi dalam Musrenbangdes. Sebagaimana menurut Suharto (2005) terdapat tujuan dalam pemberdayaan community development yaitu kemandirian, integrasi dan kemampuan masyarakat melalui perencanaan sosial untuk memecahkan masalah disebabkan ketidakadilan, tidak merata dan setara kemudian kurangnya kekampuan dan 
relasi, sehingga dilakukan aksi sosial untuk perubahan struktur, lembaga dan sumber kekuasaan.

Pentingnya pemberdayaan untuk menentukan perencanaan program pembangunan ditegaskan dalam beberapa pendapat seperti Ife dan Tesoriero (2008), bahwa pemberdayaan memiliki fungsi meningkatkan keberdayaan pihak yang dirugikan (the disadvantaged), maka terdapat unsur kekuasaan (politik) dari individu dan kelompok yang memiliki atau menggunakan kesempatan untuk meraih serta mendistribusikan kekuasan yang dimiliki yang nantinya akan menentukan bentuk karakteristik pemberdayaan. Mardikanto dan Soebianto (2012) menyatakan pemberdayaan masyarakat merupakan tahapan ada motivasi untuk memiliki hak dan keberanian untuk berubah, berpartisipasi, serta memiliki kompetensi. Berdasarkan Tifa Foundation menegaskan yang didukung Japan Social Development Fund Bank Dunia (2010-2013) melakukan kegiatan pemberdayaan dan advokasi kepada tenaga kerja wanita dan keluarganya dengan tiga program pemberdayaan, yaitu: (1) Access to justice dengan memberdayakan TKW dan keluarga supaya memahami danmeningkatkan kapasitas akan haknya. (2) Access to finance, meningkatkan kapasitas TKW dalam manajemen keuangan dan dapat mendirikan usaha kecil. (3) Access to information, memastikan TKW mendapatkan akses informasi yang dibutuhkan, dapat menghin dari penipuan, penyelundupan manusia, dan memperluas informasi mengenai prosedur administasi resmi, tujuan penempatan kerja, dan media interaksi.

Hasil dari dialog sarasehan sambung rasa dapat mengidentifkasi permasalahan dan menyepakati program kegiatan pemberdayaan yaitu (1) Hampir setiap kepala keluarga pernah menjadi Tenaga Kerja Indonesia (TKI) dan generasi muda disiapkan untuk siap melanjutkan menjadi TKI atau mnejadi TKW.

Hal tersebut dikarenakan masyarakat masih memiliki mental dan pemikirian bahwa menjadi TKW merupakan profesi yang dianggap dapat menghasilkan penghasilan yang lebih cepat dan lebih besar untuk memperbaiki ekonomi keluarga dibandingkan bertani atau berwirausaha di desa serta memperbaiki ekonomi keluarga. Sehingga masyarakat tidak memiliki keinginan melanjutkan sekolah anakanaknya ke jenjang lebih tinggi diatas SMP dan SMA. Melanjutkan sekolah dinilai sebagai beban ekonomi keluarga dan tidak menghasilkan pendapatan bagi keluarga. (2) Agen penyalur TKI dan TKW baik yang memiliki ijin resmi maupun yang ilegal dapat mudah dan leluasa mencari, membujuk dan mendapatkan jasa tenga kerja karena mendapat dukungan serta bekerjasama sengan oknumoknum serta calo tenaga kerja lokal yang mendapat konpensasi yang menguntungkan dari segi nominal. Sehingga terdapat ikatan saling menguntungkan kepentingan antara penyalur tenaga kerja, oknum, calo dan masyarakat sendiri yang inginmenjadi TKI dan TKW. Dampaknya desa ditinggalkan masyarakatnya 
dan potensi ekonomi desa seperti usaha pertanian, perkebunan, perikanan dan perdagangan tidak diminati serta terbengkalai. Prihatinah et al. (2012) menyatakan lemahnya pengawasan dan kebijakan perlindungan hukum terkait pelanggaran pidana maupun administratif dan lemahnya norma perlindungan tanpa sanksi hukum khususnya pelanggaran pengurusan administrasi.

Perekrutan yang dilakukan calo dan sponsor, tidak ada pencatatan calon tenaga kerja yang tertib dan akurat serta lemahnya pengawasan seperti tentang kualifikasi pendidikan dan keahlian. (4) Menjadi TKI dan TKW hanya dipandang dari segi keuntungan menghasilkan pendapatan yang tinggi bagi masyarakat dan menghasilkan devisa negara, padahal terdapat dampak yang lebih besar yaitu mentalitas masyarakat yang cenderung ingin instan (cepat dan mudah) mendapatkan penghasilan, potensi ekonomi desa terbengkalai, rusaknya interaksi sosial keluarga karena suami, istri dan anak berpisah cukup lama, terjadi perselingkungan, konflik terjadi, hingga meningkatnya angka perceraian di keluarga TKI dan TKW, bahkan terjadi degradasi moral yaitu pergaulan bebas serta prostitusi. Kemudian menimbulkan rasa traumatik bagi para TKI dan TKW yang gagal karena diperlakukan tidak baik ketika bekerja di luar negeri. Hasil penelitian Sutaat et al. (2011) bahwa kondisi sosial ekonomi calon tenaga kerja Indonesia dan keluarganya masuk katagori rendah, walaupun seperti terlihat pemilik dan kondisi rumah tidak menunjukan kemiskinan. Problematika sosial calon tenaga kerja Indonesia ketika sebelum berangkat tentang persyaratan dokumen yang harus dilengkapi, kondisi keluarga yang ditinggalkan seperti istri atau suami dan anak yang terbengkalai. (5) Masyarakat desa dari kaum perempuan terutama calon dan mantan TKW tidak memiliki kesempatan yang lebih terbuka untuk beraspirasi dalam proses perumusan program pembangunan atau pemberdayaan dan pengambilan keputusan di desa seperti dalam kegiatan musyawarah perencanaan pembangunan desa (Musrenbangdes). Padahal menurut Wulan (2010) TKW memiliki remiten sosial yang dapat menjadi modal untuk program dan pelaksanaan pemberdayaan, perlindungan dan advokasi terhadap komodifikasi secara menyeluruh mulai dari berangkat sampai pulang ke desa tempat asalnya.

Hasil temuan penelitian lanjutan menunjukkan komunikasi pembangunan di desa belum bersifat partisipatif dan dialogis bahwa (1) Mantan dan calon TKW kurang memiliki kesadaran pentingnya berpartisipasi dalam proses perumusan dan pengambilan keputusan tentang program pembangunan di desa yang menentukan pemberdayaan perempuan. (2) Mantan dan calon TKW tidak memiliki kesempatan untuk ikut berpartisipasi dalam perencanaan pembangunan baik ditingkat RT, RW, dusun dan desa yang masih didominasi oleh kaum laki-laki. (3) Keterwakilan perempuan dalam Musrenbang hanya diwakili oleh kelembagaan yang sudah ada seperti PKK dan Pos Pelayanan Terpadu (Posyandu), belum ada 
keterwakilan khusus seperti kelembagaan usaha ekonomi perempuan di desa dan khusus komunitas mantan TKW. (4) Pihak pemerintah desa belum mendukung penuh terhadap partisipasi mantan dan calon TKW dalam proses perumusan dan pengambilan keputusan program pembangunan desa. Padahal proses pembangunan diawali dari perencanaan yang diwadahi oleh Musrenbang RT, RW, dusun dan desa sebagai perwujudan komunikasi pembangunan secara partisipatif. (5) Proses musyawarah dalam kegiatan dialog sarasehan sambung rasa perangkat desa dan komunitas laki laki yang merupakan mantan tenaga kerja Indonesia mendominasi dalam berpendapat dan mengusulkan program kegiatan.

Sedikitnya keterwakilan perempuan dalam Musrenbang desa disebabkan oleh peranan lembaga di desa masih tetap paling banyak kaum laki-laki. Kaum perempuan masih terjebak oleh urusan domestik yaitu kegiatan rumah tangga. Kaum perempuan masih kurang memiliki keberanian untuk beraspirasi dan kritis. Representasi perempuan masih dari unsur Posyandu dan PKK, namun kesempatan dan kuantitasnya masih sedikit (Sulaiman et al. 2015). Hak perempuan mendapatkan ruang untuk aktif dalam pemberdayaan masih belum optimal mendapat perhatian dalam proses merancang program pemberdayaan atau pembangunan. Representasi perempuan menjadi faktor strategis dan penting dalam memperjuangkan kebutuhan, sumber daya dan program kegiatan pembangunan bagi perempuan (Hubeis 2010; Suadnya 2011; Kim 2012).
Padahal dalam tahun 2015-2019 di Rencana Pembangunan Jangka Menengah Nasional (RPJMN) bahwa terdapat perhatian serius terhadap keterwakilan perempuan dalam pembangunan dalam arah kebijakan strategi untuk meningkatkan kesejaheraan dan kesempatan untuk berpartisipasi bagi perempuan dibidang apapun.

Hasil wawancara dan dialog dalam sarasehan sambung rasa tahap berikutnya setelah mendapat penyuluhan dan dialog tahap awal tentang pentingnya menumbuhkan motivasi untuk bisa meningkatkan usaha ekonomi, membentuk kelembagaan dan kebersamaan, khususnya informan perempuan mengalami perubahan positif yaitu dapat melaksanakan komunikasi yang partisipatif dan dialogis seperti (1) Adanya kesadaran dan semangat untuk memberdayakan potensi sumber daya manusia, alam dan ekonomi di desa sebagai lahan pekerjaan (sumber penghasilan) sehingga tidak ketergantungan menjadi TKW ke luar negeri. (2) Kesadaran dan semangat untuk mengetahui dan memahami peraturan hukum khususnya tentang kasus dan advokasi perburuhan. (3) Membentuk komunitas calon dan mantan TKW sebagai pendiri atau pengurus awal sebagai prosedium Forum Komunikasi Pemberdayaan Perempuan Desa (FKPPD) untuk merumuskan, membuat, dan menyepakati program pembangunan yang mendukung pemberdayaan perempuan dan akan diperjuangkan dalam Musryawarah Perencanaan Pembangunan (Musrenbang) di tingkat desa. 
Sehingga kaum perempuan memiliki forum musyawarah sendiri secara khusus untuk membahas dan memperjuangkan aspirasi, hak dan kebutuhannya terutama untuk mantan serta calon tenaga kerja wanita di desa. (4) Forum FKPPD setelah terbentuk formatur pengurus sementara, selanjutnya membentuk keanggotaan dengan mengajak semua elemen perempuan terutama para mantan dan calon TKW di desa supaya bergabung mengikat dalam solidaritas dan tujuan yang sama. Setelah banyak anggota yang ingin ikut bergabung, dilaksanakan forum FKPPD untuk mensyahkan persyaratan administrasi pendirian lembaga, kemudian memilih kepengurusan tetap untuk periode yang ditentukan. (5) Kepengurusan yang tetap kemudian menyusun struktur pengurus yang mengakomodasi berbaai kepentingan perempuan seperti bidang advokasi hukum, bidang pemberdayaan ekonomi dan bidang hubungan masyarakat. Selanjutnya menyusun rencana program kerja dari berbagai bidang tersebut. Rancangan program disosialisasikan, dibahas dan disepakati oleh pengurus dan seluruh anggota dalam FPM3. (6) Forum FKPPD dirancang untuk dilaksanakan minimal dua tahun sekali yaitu pada bulan Juli sebagai proses evaluasi pelaksanaan pembangunan dan bulan desember sebagai evaluasi tahap kedua yang hasilnya sebagai dasar bagi perancangan perencanaan program pembangunan perempuan di desa. (7) Hasil FKPPD diusulkan kepada pemerintah desa, pemerintah daerah dan wakil rakyat di DPRD kabupaten dan provinsi secara lagsung komunikasi khusus. Kemudian diperjuangkan juga melalui Musrenbang di tingkat dusun, desa dan kecamatan sampai kabupaten. (8) FKPPD memiliki media komunikasi berupa blog, webside, dan buletin atau majalah untuk memberikan informasi, media aspirasi, sosialisasi, mendesiminasi dan menjadi media perjuangan bagi pemberdayaan perempuan di desa. Pengurus dan anggota FKPPD diberikan pelatihan untuk membuat, mengelola dan mengembangkan media komunikasi tersebut.

Pembentukan Forum Komunikasi Pemberdayaan Perempuan Desa (FKPPD) merupakan media interaksional untuk menghimpun solidaritas, kepekaan, empati dan saling membantu khususnya bagi mantan dan calon TKW. FKPPD diinisiasi dan didampingi oleh perguruan tinggi dan aktivis yang selanjutnya diteruskan oleh para perempuan di desa khususnya mantan TKW dan para calon TKW supaya tidak lagi menilai menjadi TKW di luar kota dan di luar negeri sebagai profesi yang paling menjanjikan kesejahteraan. FKPPD merencanakan, membuat dan mengusulkan program pemberdayaan sesuai dengan identifikasi masalah dan analisis potensi serta sumber daya bagi kaum perempuan di desa. FKPPD dapat mengaspirasikan program pemberdayaan melalui media Musrenbang dan beraudiensi dengan pemerintah atau wakil rakyat secara langsung.

FKPPD melaksanakan pemberdayaan dalam meningkatkan motivasi, pengetahuan, pemahaman serta kompetensi sesuai potensi dan sumber daya perempuan melalui kerjasama 
dengan perguruan tinggi, pihak pemerintah dan lembaga lainnya. FKPPD dapat menjamin dan meningkatkan kesejahteraan ekonomi khususnya bagi perempuan sehingga tidak lagi meninggalkan desa untuk menjadi TKW, mencegah dampak negatif menjadi TKW dan mencegah urbanisasi. Penyelesaian TKI dan TKW seharusnya dapat diselesaikan di bagian hulu yaitu masyarakat desa untuk sejahtera dan tidak meninggalkan desanya, bukan di hilir penyelesaian TKI dan TKW setelah terkena dampak negatif. Maka membentuk FKPPD menjadi kunci penting dalam melaksanakan pembangunan partisipatif. Sebagaimana menurut Purnaningsih (2009) model komunikasi bisa direalisasikan untuk mengorganisir pembangunan dalam hl ini pemberdayaan dengan model partisipasi dan kolaborasi antar pemangku kepentingan. Pambudy (2009) menjelaskan bahwa dalam melaksanakan tahapan pemberdayaan dan pembangunan, peran komunikasi merupakan persyaratan utama bagi pemangku kepentingan dalam membangkitkan semangat, melibatkan, melakukan dan penyuluhan kepada komunitas. Eligio (2011) menyatakan peranan komunikasi sebagai aktivitas pembuatan dan pemahaman makna bersama dalam proses pembuatan kebijakan yang dapat membuka jalan untuk para subjek pembangunan mengkonstruksi potensi dan sumber daya pembangunan.

Kemudian Robertson dan Choi (2012) menjelaskan inti dari peran aktif dalam forum komunikasi yaitu adanya transfer of knowledge, pengalaman dan data secara transparan, sejajar, aspirasi memiliki makna penting serta menghasilkan kesimpulan dan kesepakatan kolektif.

Berdasarkan hasil dan analisis penelitian tersebut, dapat dibuat model Forum Komunikasi Pemberdayaan Perempuan Desa (FKPPD) sebagaimana pada Gambar 2 berikut ini.

\section{Gambar 2. Model Forum Komunikasi \\ Pemberdayaan Perempuan Desa \\ (FKPPD)}

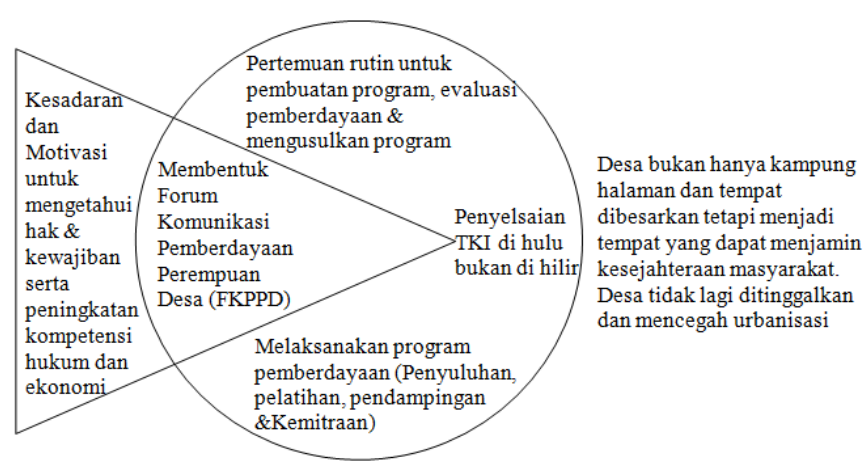

\section{SIMPULAN}

Profesi menjadi tenaga kerja di luar negeri masih menjadi orientasi masyarakat desa yang menilai akan dapat merubah nasib yang lebih baik dan lebih cepat meningkatkan mensejahterakan baik untuk dirinya maupun keluarganya. Namun tetap saja pada realitasnya menunjukan problematika yang terus muncul mulai dari tahapan administrasi, berangkat, bekerja dan pulang bekerja ke daerah asalnya.Masih terdapat oknum yang memiliki orientasi keuntungan sesaat untuk menjadikan masyarakat desa khususnya perempuan menjadi TKW ke luar kota dan luar negeri, tanpa mempertimbangkan keahlian, pendidikan dan legalitas serta jaminan keselamatan menjadi pekerja. 


\section{AKTUALISASI PEMBANGUNAN PARTISIPATIF DALAM FORUM KOMUNIKASI PEMBERDAYAAN PEREMPUAN DESA}

Desa dan Masyarakat khususnya kaum perempuan sebetulnya memiliki motivasi yang tinggi dan potensi seluruh sumber daya yang dapat dikembangkan dan meningkatkan kesejahteraan melalui program pemberdayaan. Pihak pemerintah desa sebagai pihak yang paling dekat dengan masyarakat dapat menjadi agen pemberdayaan yang serius menciptakan lapangan kerja dan mendukung tumbuhnya usaha ekonomi di desa sehingga dapat mengantisipasi masyarakatnya untuk meninggalkan desanya.

Kaum perempuan khususnya para mantan dan calon TKW dapat membuat Forum Komunikasi Pemberdayaan Peremuan Desa (FKPPD) untuk memperjuangkan aspirasi dalam Musrenbang desa, membentuk solidaritas untuk peningkatan kompetensi baik dibidang advokasi hukum, sosial dan kewirausahaan ekonomi.

FKPPD diinisiasi terlebih dahulu oleh fasilitator dan pendamping pemberdayaan dari pihak perguruan tinggi, aktivis sosial, dan pemerintah desa yang berkolaborasi mendukung peningkatan motivasi, pengetahuan, pemahaman, dan keterampilan bagi para kaum perempuan khususnya mantan TKW. FKPPD berperan untuk merencanakan, membuat, mengevaluasi dan mengusulkan program pemberdayaan berdasarkan identifikasi masalah dan analisis potensi serta sumber daya bagi kaum perempuan di desa. Usulanya dapat di aspirasikan melalui Musrenbang, beraudien dengan wakil rakyat dan pemerintah daerah. FKPPD memiliki untuk menciptakan dan meningkatkan kesejahteraan ekonomi khususnya bagi kaum perempuan, sehingga tidak lagi meninggalkan desa untuk menjadi TKW, mencegah urbanisasi dan mencegah dampak negatif menjadi TKW.

\section{REFERENSI}

Adi, I.R. (2013). Intervensi Komunitas dan Pengembangan Masyarakat sebagai Upaya Pemberdayaan Masyarakat. Jakarta : Rajawali Pers.

Bungin, H.M.B.( 2008). Sosiologi Komunikasi : Teori, Paradigma, Diskursus Teknologi Komunikasi di Masyarakat. Jakarta: Kencana.

Dasgipta, S. (2009). Sonarghachi Project : A Case Study Set in India. McPhail T.L (ed). Development Communication. United Kingdom: Willy-Blackwell.

DeVito, J. (2011). Komunikasi Antarmanusia. Tangerang Selatan: Karisma

Effendy, O.U.( 2005). Ilmu Komunikasi: Teori dan Praktek. Bandung : Rosdakarya

Eligio, E.M.JE. (2011). Communication imperatives for indigenous peoples' representation in policy making: Lessons from the IPRA (Indigenous Peoples Rights Act) experience. Telematics and Informatics. 29 (3):324334

Fisher, B., Aubrey,. \& Katherine, L.A. (1994). Interpersonal Communication: Pragmatics of Human Communication. New York: McGraw-Hill 
Hubeis, A.V. (2010). Pemberdayaan Perempuan dari Masa ke Masa. Bogor: IPB Press

Ife, J., \& Tesoriero. (2008). Community Development: Alternatif Pengembangan Masyarakat di Era Globalisasi. Manullang S, Yakin N, Nursyahid M, penerjemah. Yogyakarta : Pustaka Pelajar. Judul asli Community Development : Community-Based Alternatives in an Age of Globalisation

Kim, D.W. (2012). Hearing the Unsung Voice: Women in the Qumran Community. International Journal of Humanities and Social Science. 2(19): 275-282

Mardikanto, T., \& Soebianto. (2012). Pemberdayaan Masyarakat : dalam Perspektif Kebijakan Publik. Bandung: Alfabeta.

Mikkelsen, B. (2011). Metode Penelitian Partisipatoris dan Upaya Pemberdayaan Penerjemah : Matheos Nalle. Jakarta : Yayasan Pustaka Obor Indonesia

Miles, M.B., \& Huberman A.M. (2007). Analisis Data Kualitatif. Rohidi TR, penerjemah. Jakarta : UI Press

Muchlis, F. (2009). Analisis Komunikasi Partisipatif dalam Program Pemberdayaan Masyarakat (Studi Kasus pada Implementasi Musyawarah dalam PNPM Mandiri Perdesaan di Desa Teluk Kecamatan Pemayung Kabupaten Batang Hari) [Tesis]. Bogor : Institut Pertanian Bogor
Pambudy, R.( 2009). Pola Komunikasi Pembangunan dan Kebijakan Publik. Prosiding Seminar Nasional. Komunikasi Pembangunan Mendukung Peningkatan Kualitas Sumber Daya Manusia dalam Kerangka Pengembangan Masyarakat. Kamis, 19 November 2009. IPB International Convention Center (IPB ICC) Bogor: 67-77

Porras, L.E \& Steeves, H.L.( 2009). Feminism in a Post-Development Age : McPhail, Thomas L, editor. Development Communication : Reframing The Role of The Media. Malden, Oxford : Blackwell Publishing Ltd.

Prihatinah, T.S., Asyik, N., \& Kartono, (2012). Kendala Perlindungan Hukum terhadap Buruh Migran di Kabupaten Cilacap. Jurnal Dinamika Hukum. 12(2): 312-320

Purnaningsih, N. (2009). Pendekatan Komunitas dan Komunikasi Sosial pada Pengembangan Sistem Penyediaan Air Minum (SPAM). Sodality: Jurnal Transdisiplin Sosiologi, Komunikasi, dan Ekologi Manusia. IPB Bogor. 3(3): 379-394

Rangkuti, P.A. (2011), Komunikasi Pembangunan dan Mekanisasi Pertanian. Bogor: IPB Pers.

Robertson, P.J., \& Choi, T. (2012). Deliberation, Consensus, and Stakeholder Satisfaction : A simulation of collaborative Governance. Public Management Review. 14(1): 83-103

Satriani, I. (2011). Komunikasi Partisipatif pada Program Pos Pemberdayaan Keluarga (Studi Kasus di RW 05 Kelurahan Situgede Kecamatan Bogor Barat Kota Bogor) [Tesis] Mayor 
Komunikasi Pembangunan Pertanian dan Pedesaan. Bogor : Institut Pertanian Bogor

Suadnya, I.W. (2011). Perencanaan Partisipatif Dalam Pembangunan Daerah di Kabupaten Lombok Barat: Antara Konsep dan Realita. Agroteksos. (21)1: $62-70$

Subianto, A. (2006). Pengaruh Pemanfaatan Remitan Tenaga Kerja Wanita (TKW) Terhadap Pertumbuhan Ekonomi Wilayah di Kabupaten Cilacap (Studi Kasus di Kecamatan Adipala, Kecamatan Binangun dan Kecamatan Nusawungu). [Tesis]. Pascasarjana Universitas Diponegoro

Suharto, Edi. (2005). Membangun Masyarakat, Memberdayakan Masyarakat: Kajian Strategis Pembangunan Kesejahteraan Sosial dan Pekerjaan Sosial. Bandung: Refika Aditama

Sulaiman, A.I. (2013). Model Komunikasi Formal Dan Informal Dalam Proses Kegiatan Pemberdayaan Masyarakat. Jurnal Penelitian Komunikasi. 16(2): 173-168

, Lubis, D.P., Susanto, J., \& Purnaningsih, N. 2015. Komunikasi Stakeholder dalam Musyawarah Perencanaan Pembangunan (Musrenbang). Mimbar.3(2):367-378

Sutaat., Setiti, S.G., Widodo, N., \& Unayah, N.( 2011). Pendampingan Sosial Bagi Calon Pekerja Migran dan Keluarganya di Daerah Asal. Nitimihardjo C, editor. Jakarta :P3KS Press.

Syahyuti. (2006). Tiga Puluh Konsep Penting dalam Pembangunan Pedesaan dan Pertanian. Jakarta: Bina Rena Pariwara.
West, R., \& Turner, L.H. (2008). Introducing Communication Theory: Analysis and Application. New York (US): McGrawHill

Wulan, T.R. (2010). Pengetahuan dan Kekuasaan : Penguatan Remitan Sosial sebagai Strategi Pemberdayaan Buruh Migran Perempuan. [Disertasi]. Pascasarjana IPB

Sumber lain:

[BNP2TKI]. "2.949 Pengaduan Kasus TKI di Proses NTP2TKI". [internet]. [diunduh 29 September 2017]. Tersedia pada : http://www.bnp2tki.go.id

[detiknews]. "Sepanjang 2017, Ada 148.285 TKI Ditempatkan di Luar Negeri". [internet]. [diunduh 27 September $\left.20 \begin{array}{lll}2 & 1 & 7\end{array}\right]$. Tersedia pada: https://news.detik.com

[Migrant CARE]. "Memperingati Hari Kartini: Kartini Masa Kini Adalah Pekerja Migran". [internet]. [diunduh 21 April $\left.\begin{array}{llll}2 & 0 & 1 & 8\end{array}\right]$. Te r sedia pada : http://www.migrantcare.net

[Polhukam]. DPRD Cilacap Fokus Bahas Raperda Perlindungan Tenaga Kerja Wanita (TKW). [internet]. [diunduh 18 Pebruari 2018]. Tersedia pada : http://polhukam.rmol.co/read

[Tifa Foundation]. Penutupan Program Pemberdayaan Buruh Migran Perempuan dan Keluarganya di Daerah Asal. [internet]. [diunduh 9 Pebruari $\left.\begin{array}{llll}2 & 0 & 1 & 8\end{array}\right]$. Te r sedia pada: http://www.tifafoundation.org 